\title{
DETERMINANTS OF CAPACITY BUILDING NEEDS OF ARTISANAL FISHERS IN KOGI STATE, NIGERIA
}

\author{
R. Solagberu Adisa ${ }^{1}$, Ifabiyi J.O ${ }^{1}$, Opeyemi Gbenga ${ }^{2}$ \\ ${ }^{1}$ Department of Agricultural Extension and Rural Development, Faculty of Agriculture, University of \\ Ilorin, PMB 1515, Ilorin, Nigeria. \\ ${ }^{2}$ Department of Agricultural Economics and Extension, Kogi State University, Anyigba, Nigeria \\ *Corresponding author: rsadisa@yahoo.com
}

Citation: Adisa, R.S., Ifabiyi J.O., Gbenga, O., 2021. Comparative Analysis of Income Differentials between Men and Women in Urban and Rural Households in Bayelsa State, Nigeria.. J. Asian Rur. Stud. 5(1): 78-89

\begin{abstract}
Nigerians are high fish consumers as the per capita consumption is $14.9 \mathrm{~kg}$ per year and has the largest market for fish and fishery products in Africa. Artisanal fishers provide fish for large proportion of fish consumed by our teeming population. These set of fishers depend on crude gears and technology and small vessels in capturing multiple fish species. This study examined the determinants of the capacity building needs of artisanal fishers in Kogi State, Nigeria. The study used primary data. The primary data were collected using structured questionnaire. Multistage sampling technique was use to select the respondents. A total number of 292 respondents were selected for the study. Data were analyzed using frequency, percentage, mean and Binary Logistic Regression. The results showed that more than half (71.6\%) of the respondents had low knowledge level and majority $(87.0 \%)$ of the respondents had high capacity building needs. The educational status $(\mathrm{p}<0.10)$, years of experience in fishing activities $(p<0.10)$, contacts with extension services $(p<0.01)$ and craft type $(p<0.05)$ are the determinants factors of capacity building needs of the artisanal fishers. The study concluded that the majority of the fisher folks had low knowledge level on fishing practices. Majority of the fisher folks had high capacity building needs. The study therefore recommends the provision of training in the areas of high capacity building needs and that there should be consideration of factors influencing the capacity building needs of artisanal fisher folks during the planning and implementation of any training programme on artisanal fisheries.
\end{abstract}

Keywords: Artisanal Fishers; Fisher folks; Capacity Building Needs

\section{Introduction}

Fish is an important source of nutritious and affordable food for Low income people in the world (Bene et al., 2015). Fisheries make a vital contribution to global food and nutrition security as FAO (2018) reported that about 88.42 percent of the total 171 million tons of fish produced were consumed by man. Fish accounts for about 17 percent of animal protein consumed by the global population (FAO, 2018). Nigerians are high fish consumers as the per capita consumption is $14.9 \mathrm{~kg}$ per year and has the largest market for fish and fishery products in Africa (FAO, 2016; Olaoye and Oloruntoba, 2011). Fish products and foods are consumed in Nigeria because of their high protein contents and their relatively cheap prices when compared with meat (FAO, 2012). Its amino acid profile, low cholesterol content, high vitamins and minerals content (calcium, iron, zinc), as well as fatty acid profile makes it stands out among animal proteins (FAO, 2012). Although fish is highly susceptible to 
deterioration without any preservative measures, fish currently constitutes $41 \%$ of total animal protein intake by the average Nigerian and is increasingly a substitute for meat due to health and nutrition considerations (Okonta and Ekelemu, 2005).

Artisanal fishers depend on crude gears and technology and small vessels in capturing multiple fish species. Artisanal fishing is the process of capturing fish from the natural water using traditional gears and crafts. According to FAO (2008), artisanal fisherfolks are smallscale fishers who are into fishing activities on a part-time or full-time basis to make money and also for consumption purposes. The key features of artisanal fisheries are that it depends on crude technology which involves the use of small boats and canoes, different types of fishing gears, mostly operate close to the river banks and coastal areas, labour intensive, low capital outlay and catches small quantities of different species of fish (FAO, 2008; Onuoha, 2009; Sumaila, 2017; Gibson and Sumaila, 2017 and Ifabiyi et al.,2017). The artisanal fishery provides income and employment for the fisherfolks and supplies cheap protein for the populace. Sustainable artisanal fishery practices are idea and hygienic fish capturing, handling, processing, preservation and marketing. Knowledge and adherence to sustainable fishing practices would make fish to be available continually in the water bodies, ensure the production of good quality fish products and would maximize the profit of the fisherfolks.

Capacity building is the acquisition of skills and knowledge required to perform a task better (Ifabiyi, Banjoko and Komolafe, 2017). Capacity building is the effort geared towards improving the level of knowledge, skills and attitude possessed by an individual for proficiency in a given task or job. Capacity building would improve the skills, knowledge and attitude of the fisherfolks. Capacity building needs is the skill, knowledge and attitude an individual requires to overcome problem as well as to avoid creating problem situation (Owona et al., 2010). Capacity building needs also refers to additional specific information, knowledge and skills required to perform certain operation or activities (Ifabiyi, 2019).

The artisanal fisheries could contribute to national economic growth if they received opportunities to become more productive as the population increases, the demand for fish and fish products increases, especially with its nutritional advantage over meat. Alagoa, Elo, Andew and Ojukuli (2011) reported that the demand for fish in Nigeria is increasing at an annual rate of 3\%. However, artisanal fisheries are fast depleting (Kapadia, 2002). The World Fish Center, as reported by Dambatta and Sogbesan (2015), stated that enormous potentials of fisheries to help feed and improve the nutritional status of Nigerians are greatly under-realized and precious aquatic resources are being degraded. The technologies in artisanal fishery in Nigeria are poor and crude, as post-harvest losses is as high as between $30-50 \%$ (Olowoniyan, Bolorunduro, Dikko and Chindo, 2013 and FAO, 2007). Kyangwa and Odongkara (2005) attributes the high post-harvest losses and the low quality of fish products to the procedural techniques employed by the fisherfolks. The result of this is economic losses to fishermen, fish farmers, fish processors and marketers (Bolorunduro, 1996). Studies on the factors influencing the fisherfolks' areas of capacity building needs are necessary so as to know the right intervention to make. The main objective of this study was to examine the determinants of capacity building needs of artisanal fishers in Kogi State, Nigeria. The specific objectives were to determine the artisanal fishers' knowledge level on sustainable artisanal fishery practices in the study area; identify perceived areas of capacity building needs of artisanal fishers in the study area; and to identify the factors influencing fisherfolks' capacity building needs. 


\section{Methods}

The study was conducted in the Kogi State, North-central, Nigeria. Kogi State is located in the North-Central geo-political zone of Nigeria. It extends from latitudes $6.33^{\circ} \mathrm{N}$ to $8.44^{\circ} \mathrm{N}$ and from longitudes $5.40^{\circ} \mathrm{E}$ to $7.49^{\circ} \mathrm{E}$. The State covers a land area of about 75,000 square kilometers. Out of these, about $20 \%$ of the land is occupied by people $(15,000$ sq kilometers). The population for the study consists of all the artisanal fishers in the Local Government Areas (LGAs) along the River Niger bank in Kogi State, North Central, Nigeria. Three -stage sampling procedure was used to select the respondents for this study. The first stage involved a purposive selection of Local Government Areas (LGA) located along the River Niger banks in Kogi State, Nigeria where there is high rate of fishing activities (see selected LGAs in Kogi State: Lokoja, Idah and Koton-karfe LGAs).

The second stage involved a random selection of 5 fishing communities per selected LGA. A total of 15 fishing communities were selected. The third stage involved a proportionate random sampling of $10 \%$ of the population of the fisherfolks from the selected fishing communities. A total of 292 respondents were selected for this study.

To determine the knowledge of the respondents on fishing practices, 22 knowledge statement were provided on a scale of yes and no, where $\mathrm{Yes}=1$ and No $=0$. The Respondents with knowledge score of $\leq 50 \%$ (1-50\%) were categorized as having Low Knowledge Level while those that has Knowledge score range of between 51-100\% were categorized as High Knowledge Level. The perceived areas of capacity building need were determined on a set of 18 fishing task statements where Capacity building needed $=1$ and capacity building not needed $=0$.

To determine the factors influencing the capacity building needs, Binary logistic regression was used where dependent variable $\left(\mathrm{Y}_{\mathrm{i}}\right)=$ Capacity Building Needs $($ High Need $=$ 1 , Low Need $=0$ ) and the independent variable $\left(\mathrm{X}_{\mathrm{i}}\right)=$ ( age, gender, educational level, marital status, years of experience, income, household size, quantity of catch, contact with extension agents, fishing craft, number of fishing trips). The data was analyzed using frequency, percentage, mean and Binary Logistic Regression.

\section{Logit Regression Model}

$$
\begin{aligned}
& Y_{i}=l i\left(\frac{P_{i}}{1-P}\right)=\beta+\beta 1 X 1+\beta 2 X 2+\cdots+\beta i X i- \\
& Y_{i}=\beta+\sum_{i=1}^{n} \beta_{i X_{i}+U_{i}}-
\end{aligned}
$$

\section{Measurement of variables}

$\mathrm{Y}_{\mathrm{i}}=$ Capacity Building Needs (High Need $=1$, or Low Need $=0$ ),

$\mathrm{X}_{1}=$ Age of the artisanal fish farmer (years),

$\mathrm{X}_{2}=$ Marital status (Numerical: single $=1$, Married =2),

$\mathrm{X}_{3}=$ Educational level (years of schooling),

$\mathrm{X}_{4}=$ Years of experience (in years),

$\mathrm{X}_{5}=$ Income (Naira),

$\mathrm{X}_{6}=$ household size (actual number),

$\mathrm{X}_{7}=$ Labour type (hired $=1$, family $=0$ ),

$\mathrm{X}_{8}=$ Membership of association (actual number),

$\mathrm{X}_{9}=$ Quantity of catch per day $(\mathrm{Kg})$, 
$\mathrm{X}_{10}=$ Contact with extension agents (dummy: Extension contact $=1$, or No contact $=2$ ),

$\mathrm{X}_{11}=$ other supportive occupation (dummy: other supportive occupation $=1$, or otherwise $=0$ ),

$\mathrm{X}_{12}=$ Craft type

$\mathrm{X}_{13}=$ Number of fishing trips (actual number),

\section{Results and Discussion}

\subsection{Background Information of the Respondents}

This section presents and discussed the research findings of the background information of the respondents. This section (Table 1) presents the Socio-economic characteristics of respondents in the study area include: age, gender, marital status, educational level, household size, membership of association, Contact with Extension Service, primary occupation and annual income among others.

Table 1: The Result of Background Information of the Respondents

\begin{tabular}{|c|c|c|c|c|}
\hline Socio-economic Characteristics & Frequency & Percentage & Mean & S.D \\
\hline \multicolumn{5}{|l|}{ Gender } \\
\hline Male & 288 & 98.6 & & \\
\hline Female & 4 & 1.4 & & \\
\hline Age (Year) & & & 46.2 years & \pm 12.0 \\
\hline $20-30$ & 38 & 13.0 & & \\
\hline $31-40$ & 63 & 21.6 & & \\
\hline $41-50$ & 83 & 28.4 & & \\
\hline $51-60$ & 80 & 27.4 & & \\
\hline $61-70$ & 26 & 8.9 & & \\
\hline Above 70 & 2 & 0.7 & & \\
\hline \multicolumn{5}{|l|}{ Marital Status } \\
\hline Single & 22 & 7.5 & & \\
\hline Married & 249 & 85.3 & & \\
\hline Separated & 15 & 5.1 & & \\
\hline Widowed & 6 & 2.1 & & \\
\hline \multicolumn{5}{|l|}{ Educational Status } \\
\hline No formal & 101 & 34.6 & & \\
\hline Primary & 112 & 38.4 & & \\
\hline Secondary & 53 & 18.1 & & \\
\hline Tertiary & 26 & 8.9 & & \\
\hline \multicolumn{5}{|l|}{ Membership of Association } \\
\hline Yes & 63 & 21.6 & & \\
\hline No & 229 & 78.4 & & \\
\hline \multicolumn{5}{|l|}{ Contact with Extension Service } \\
\hline Yes & 64 & 21.9 & & \\
\hline No & 228 & 78.1 & & \\
\hline \multicolumn{5}{|l|}{ Fishing as Primary Occupation } \\
\hline Yes & 134 & 45.9 & & \\
\hline No & 158 & 54.1 & & \\
\hline \multicolumn{5}{|l|}{ Other Supportive Occupation } \\
\hline Farming & 146 & 50.0 & & \\
\hline Trading & 75 & 25.7 & & \\
\hline
\end{tabular}




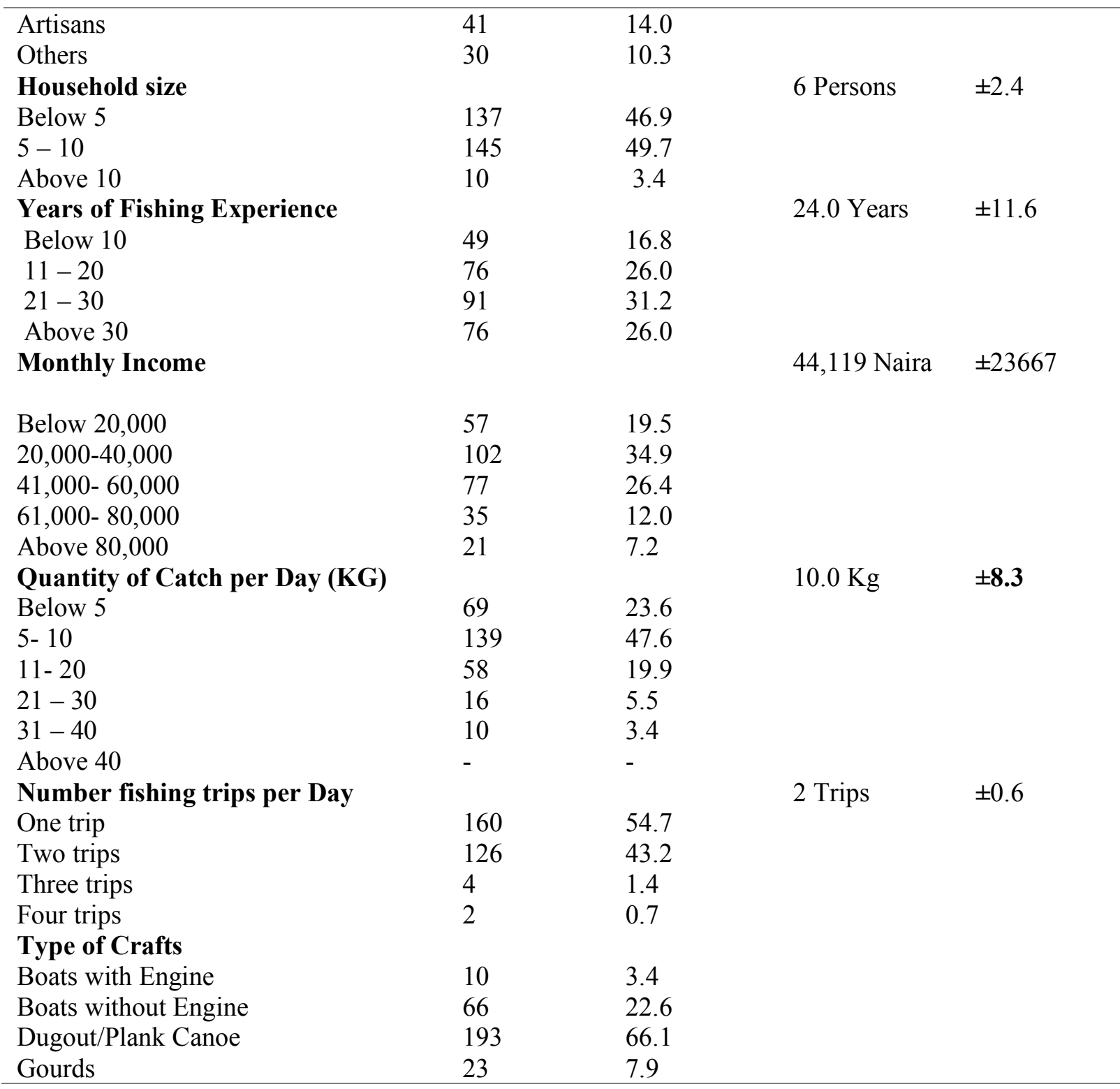

Source: Author's Field Survey 2018, S.D - Standard Deviation

The result in Table 1 reveals that majority $(98.6 \%)$ of the fishers were male. This indicates that artisanal fishing is dominated by male which might be due to the strenuous nature of fishing activities. The average age of the respondents was 46.2 years. This indicates that the fisherfolks were young, agile and are within the economically active age to undertake strenuous tasks associated with fishing activities. This further implies that fishing activities requires much energy in which children and elderly people might not be able to participate fully. The result in Table 1 further revealed that majority $(85.3 \%)$ of the respondents were married. The implication of majority of respondents being married is that family members could be of great assistance in artisanal fishing operations. The result in Table 1 revealed that about $38.4 \%$ of the respondents had primary education. This indicated that fisherfolks had low level of education. This study is in agreement with the findings of Dogondaji et al, (2009) who revealed that fishermen had low levels of education.

The result further revealed that higher percentage (78.4\%) of the respondents does not belong to any association. Membership of fishing association can enhance productivity as 
fishers can exchange useful information. Also, extension agents can make use of this platform to provide information on improved fishing practices. Furthermore, membership of association will enhance fisherfolks' accessibility to credit which will enable them to overcome financial constraints. The result in Table 1 revealed that majority $(78.1 \%)$ had no contact with extension services. This implies that majority of the fisherfolks do not have access to information on improved fishing practices as they had no contact with the extension services. Access to adequate information through fishery extension services is essential for increased artisanal fishery productivity.

The result in Table 1 revealed that about $45.9 \%$ of the respondents practiced fishing as primary occupation and about $50 \%$ of the respondents practice farming as supportive occupation. The result also revealed that the average household size of the respondents was 6 persons. This implies that the fisherfolk's household size could have influence on their output and income. This indicates that the respondents have family dependents that will require more financial commitment which might propel them to acquire training in order to increase their fishing capacity and income. The average years of experience in fishing activities of the respondents was 24 years. Years of working experience has a lot to do with productivity and efficiency. The implication of this result is that majority of the respondents had some experience in fishing business. The average monthly income of the respondents was $\$ 44,119$. This is equivalent to USD 96.5. The average monthly income is higher than the current national minimum wage of $\$ 30,000$ Naira. This indicates that artisanal fishing is a viable means of livelihood. The average quantity of fish catch per day was $10 \mathrm{Kg}$.

The result in Table 1 revealed that the average number of fishing trips per day was 2 fishing trips. This could be attributed to the strenuous nature of fishing activities, lack of cold storage facilities, long distanced fishing trips and delay in selling the captured fish. The result further revealed that about $66.1 \%$ of the respondents uses dugout/plank canoe for their fishing activities. This indicates that dugout/plank canoes are important fishing craft as higher percentage of the fisherfolks utilized it for fishing activities. This could be attributed to the fact that majority of the fisherfolks depends on crude technology for their fishing activities.

\subsection{Knowledge of Sustainable Artisanal Fishery Practices}

The respondents' knowledge of Sustainable artisanal fishery practices in the study area is presented in the following Table.

Table 2: Percentage Distribution of Respondents based on Knowledge of Sustainable Artisanal Fishery Practices

\begin{tabular}{llll}
\hline & Knowledge Area & Frequency & Percentage \\
\hline 1. & Can identify all the various local species of fish & 156 & 53.4 \\
2. & Fish abundance and diversity vary seasonally & 169 & 57.9 \\
3. & $\quad$ Use of non-selective fishing nets makes artisanal fishing to be & 36 & 12.3 \\
$\quad \begin{array}{l}\text { unsustainable } \\
\text { 4. }\end{array} \quad$ Boat and other equipment should be cleanse before each fishing trip & 138 & 47.3 \\
5. & $\begin{array}{l}\text { Poor on board handling, exposure to high temperature and sun leads to } \\
\quad \text { damaged fish }\end{array}$ & 176 & 60.3 \\
6. & Fish captured in dirty and polluted water can harm the consumer & 64 & 21.9 \\
7. & Knowledge of fishing regulations and Acts & 60 & 20.5 \\
8. & Handling fish when sick (i.e. diarrhea, vomiting etc.) can contaminate the & 138 & 47.3 \\
\hline
\end{tabular}


fish.

9. Use of pesticides or any chemicals substances for fishing activities leads to $165 \quad 56.5$

decline in fish harvest

10. Drying is a way of preserving fish and is often done through the use of salt $253 \quad 86.6$

and sun radiation.

11. Placing smoked fish on a raised platform prevents uptake of moisture and $22 \quad 7.5$

insect infestation.

12. All materials used in packing fish must be clean and designed for food. $\quad 159 \quad 54.5$

13. Packing smoked fish into wooden boxes/jute bags before transportation can 161

prevent fish breakages

14. Can improves smoked fish appearance and preservation through the use of $187 \quad 64.0$ vegetable oil.

15. Keeps record of fishing activities.

16. Value addition initiatives increases the profit margin $165 \quad 56.5$

17. Unfavourable and harsh climatic condition (drought, flooding, harmattan) $209 \quad 71.6$

reduces fish harvest

18. Uncontrolled and excessive fishing can make fish species go into extinction $57 \quad 19.5$

19. Use of waste products like rubber, nylon or oil during fish smoking can $35 \quad 35$

impact high content of polycyclic aromatic hydrocarbon (PAH) on the smoked fish.

20. Can accurately forecast local weather 53

Uncovered cuts/injury can become infected with germs and then increase

the risk of fish contamination with germs.

22. Fish should be processed or preserved with ice as soon as possible to $\quad 250 \quad 85.6$ prevent spoilage.

Source: Author's Field Survey 2018

The Table 2 revealed that about $85.6 \%$ of the respondents had knowledge that fish should be processed or preserved with ice as soon as possible to prevent spoilage, about $86.6 \%$ of the respondents knows that fish should be dried through the use of salt and sun radiation and about $71.6 \%$ had knowledge that unfavorable and harsh climatic condition (drought, flooding, harmattan) reduces fish harvest. This result implies that the fisher folks are well knowledgeable in fish preservation practices. The result in Table 2 also revealed that about $7.5 \%$ of the respondents knows that placing smoked fish on a raised platform prevents uptake of moisture and insect infestation, about $12.3 \%$ knows that the use of non-selective fishing nets makes artisanal fishing to be unsustainable and about $19.5 \%$ knows that uncontrolled and excessive fishing can make fish species go into extinction. This implies that there is gap in the fisher folk's knowledge level. This could be attributed to the poor extension services on fishery practices in Nigeria as Samson (2006) reported that fishery extension services in Nigeria are inadequate and ineffective. This result is similar to the findings of Adesoji and Kerere (2013) who reported that fisher folks in Lagos State had low knowledge level on improved fishing techniques and management practices.

\subsection{Knowledge Level on Sustainable Artisanal Fishery Practices}

Table 3, presents the result of the distribution of the respondents' knowledge level on sustainable artisanal fishery practices when categorized into Low and High in the study. 
Table 3: Percentage Distribution of Respondents' Knowledge Level on Sustainable Artisanal Fishery Practices

\begin{tabular}{|c|c|c|c|}
\hline Knowledge Level & Percentage & Frequency & Percentage \\
\hline High & $100-51$ & 83 & 28.4 \\
\hline Low & $50-01$ & 209 & 71.6 \\
\hline
\end{tabular}

Source: Author's Field Survey 2018

The result in Table 3 revealed that more than half $(71.6 \%)$ of the respondents had low knowledge level while about $28.4 \%$ had high knowledge level. This implies that artisanal fisher folks' knowledge of fishing practices is not adequate and the need for training arises as a result of deficit situation in knowledge level. This could be attributed to the fact that the contact with extension services are low (Samson, 2006). This result is in agreement with the findings of Raji, et al., (2012) who reported that artisanal fisher folks had low knowledge level on modern fishing practices.

\subsection{Perceived Areas of Capacity Building}

The Perceived Areas of Capacity Building Needs of the Respondents on Fishing Practices is presented in Table below.

Table 4: Percentage Distribution of Respondents based on Perceived Areas of Capacity Building Needs of the Respondents on Fishing Practices.

\begin{tabular}{lll}
\hline Fishing Tasks & $\begin{array}{l}\text { Need Capacity } \\
\text { Building }\end{array}$ & $\begin{array}{l}\text { Need No Capacity } \\
\text { Building }\end{array}$ \\
\hline & Frequency (\%) & Frequency (\%) \\
1. Identification and sorting of fish & $181(62.0)$ & $111(38.0)$ \\
2. Handling and transportation of captured fish from & $235(80.5)$ & $57(19.5)$ \\
landing site & & \\
3. Use and repair of nets, cage and traps & $192(65.8)$ & $100(34.2)$ \\
4. Use and maintenance of multiple hooks on a line & $248(84.9)$ & $44(15.1)$ \\
5. Canoe use and maintenance & $229(78.4)$ & $63(21.6)$ \\
6. Icing of fish & $79(27.1)$ & $213(72.9)$ \\
7. Outboard engine use and repairs & $82(28.1)$ & $210(71.9)$ \\
8. Rescue, resuscitation and safety skill & $100(34.2)$ & $192(65.8)$ \\
9. Use of chorkor smoker & $242(82.9)$ & $50(17.1)$ \\
10. Drying of fish & $123(42.1)$ & $169(57.9)$ \\
11. Salting of fish & $137(46.9)$ & $155(53.1)$ \\
12. Branding/packaging of processed & $128(43.8)$ & $164(56.2)$ \\
13. Management of storage pest & $116(39.7)$ & $176(60.3)$ \\
14. Fish marketing and distribution & $239(81.8)$ & $53(18.2)$ \\
15. Record keeping & $89(30.5)$ & $203(69.5)$ \\
16. Credit Acquisition & $204(69.9)$ & $88(30.1)$ \\
17. Maintaining personal and environmental health & $185(63.4)$ & $107(36.6)$ \\
hygiene & & \\
18. Local weather forecasting & $221(75.7)$ & $71(24.3)$ \\
\hline
\end{tabular}


The result in Table 4 revealed that about $84.9 \%$ of the respondents required capacity building on use and maintenance of multiple hooks on a line, about $82.9 \%$ required capacity building on choker smoker, $81.8 \%$ of the respondents required capacity building on fish marketing and distribution, $75.7 \%$ required capacity building on local weather forecasting and about $65.8 \%$ required training on the use and repair of nets, cage and traps. This result shows that most of the fisher folks are not skillful in canoe use and maintenance, use and maintenance of multiple hooks, use of chorkor smokers and fish marketing and distribution. These high percentages of capacity building need indicates that most of the fisher folks have inadequate access to extension services. This result is in agreement with the findings of Onyebinama and Onyebinama (2010) who reported that most of people who are into agricultural practices in Nigeria had low technical and managerial skills.

\subsection{Level of Capacity Building}

Table 5, presents the result of the distribution of the respondents based on Level of Capacity Building Needs on Artisanal fishing practices in the study. Table 5 shows the level of Capacity building needs on artisanal fishing practices when categorized into Low needs and High needs.

\section{Table 5: Distribution of Respondents based on Level of Capacity Building Needs on Artisanal fishing practices}

\begin{tabular}{lll}
\hline Capacity Building Needs Level & Frequency & Percentage \\
\hline Low Needs & 38 & 13.0 \\
High Needs & 254 & 87.0
\end{tabular}

Source: Author's Field Survey, 2018. Low Needs - requires capacity building in less than 9 fishing tasks; High Needs - requires capacity building in more than 9 fishing tasks.

The result in Table 5 revealed that majority $(87.0 \%)$ of the respondents had high capacity building needs while $13.0 \%$ had low capacity building needs. This indicates that most of the fisher folks required high level of capacity building on fishing practices. Provision of required training on artisanal fisheries will improve their production, income and standard of living. This result is in agreement with the findings of Okwu, et al., (2011) who reported that the artisanal fisher folks in Benue State, Nigeria had high level of information needs on fishery practices.

\subsection{Identify Determinants of the Artisanal Fishers' Capacity Building}

Capacity Building Needs of the study were assessed using Logistic regression model and presented in Table 6 below. Explanatory variables in the study includes age, marital status, education status, years of experience, income, Household size, Labour Type, Membership of Fishing Association, Quantity of catch per day, Contact with Extension, 
Table 6: Result of Logistic Regression Analysis to Identify Determinants of the Artisanal Fishers' Capacity Building Needs on Fishing Practices

\begin{tabular}{|c|c|c|c|c|}
\hline Variables & Coefficient & $\begin{array}{l}\text { Standard } \\
\text { Error }\end{array}$ & z-value & p-value \\
\hline Constant & -2.8678 & 2.1806 & -1.32 & 0.188 \\
\hline Age & 0.0049 & 0.0294 & 0.17 & 0.867 \\
\hline Marital status & 0.6823 & 0.6190 & 1.10 & 0.270 \\
\hline Education status & 0.3448 & 0.1931 & 1.79 & $0.074 *$ \\
\hline Years of Experience & -0.0497 & 0.0286 & -1.74 & $0.082 *$ \\
\hline Income & -0.0011 & 0.0118 & -0.92 & 0.360 \\
\hline Household size & 0.1582 & 0.1107 & 1.43 & 0.153 \\
\hline Labour Type & 0.1061 & 0.2240 & 0.47 & 0.636 \\
\hline Membership of Fishing Association & -0.0349 & 0.5808 & -0.06 & 0.952 \\
\hline Quantity of catch per day & -0.0246 & 0.0268 & -0.92 & 0.359 \\
\hline Contact with Extension & 0.5815 & 0.1958 & 2.97 & $0.003 * * *$ \\
\hline Other Supportive occupation & 0.1981 & 0.2597 & 0.76 & 0.446 \\
\hline Craft Type & 0.4583 & 0.2306 & 1.99 & $0.047 * *$ \\
\hline Number of fishing trip & 0.4381 & 0.3712 & 1.18 & 0.238 \\
\hline \multicolumn{5}{|l|}{ Prob $>\mathrm{Chi}^{2}=0.0219$} \\
\hline \multicolumn{5}{|l|}{ Pseudo R2 $=0.1115$} \\
\hline Log likelihood $=-100.31062$ & & & & \\
\hline
\end{tabular}

The binary logistic regression model with four predictors produced Pseudo $\mathrm{R}^{2}=0.1115, \mathrm{P}$ $<0.001$. The Pseudo R-squared value indicates that 11.15 percent of the variation in the capacity building need is explained by the independent variables. It has been opined that studies in fields that attempt to predict human behavior typically have low $\mathrm{R}^{2}$ values as humans are harder to predict than physical processes (Martin, 2012). Educational status: The result in Table 6 showed that the years of fishing experience has a positive coefficient $(0.3448)$ and also a determinant of capacity building needs on fishing practices $(p<0.10)$. This suggest that an increase in the level of education will likely increase the fisher folks' capacity building needs. Education will enable a fisher to make independent choice and act on the basis of the decision. Years of Experience: The result showed that years of fishing experience has a negative coefficient (-0.0497) and also a determinant of capacity building needs on fishing practices $(p<0.10)$. This result implies that the higher the years of fishing experience, the lower the capacity building needs of the respondents. This implies that wealth of experience has influence on the fisher folks' skills. This may be expected as the fisher folks must have acquired enough fishing skills over the years. This result agrees with the findings of Alarima et al., (2011) who reported that training needs of rice farmers in Nigeria decreases with increase in the years of farming experience.

Contact with Extension Services has a positive coefficient (0.5815) and also a significant factor influencing fisher folks' capacity building needs $(p<0.01)$. This implies that the higher the number of contacts with extension services, the more the areas of capacity building needs of the fisher folk. This might be attributed to the effectiveness of extension services in providing relevant information to the fishers. This result agrees with the findings of Etwire et al., (2013) who reported that increase in number of contacts with extension services increases the farmers' likelihoods of participating in farmer associations in Northern region of Ghana. Craft Type has a positive coefficient $(0.4583)$ and has a significant relationship with capacity building needs $(\mathrm{p}<0.05)$. A unit increase in number of crafts used for fishing activities will 
increase the fisher folks' capacity building needs. This implies that acquisition of additional fishing craft would activate their capacity building needs.

\section{Conclusion}

The study examined the determinants of capacity building needs of artisanal fishers in Kogi State, Nigeria. Based on the findings of this study, the study concluded that the majority of the fisher folks had low knowledge level on fishing practices. Majority of the fisher folks had high capacity building needs. The areas of capacity building needs are on canoe use and maintenance, use and maintenance of multiple hooks, use of chorkor smokers and fish marketing and distribution. The educational status, years of experience on fishing activities, contacts with extension services and craft type are the determinant factors of capacity building needs of the fisher folks.

\section{References}

Adesoji S.A \& Kerere F.O (2013) Assessment of the knowledge level of fishers and fish farmers in Lagos State, Nigeria. International Journal of Knowledge, Innovation and Entrepreneurship, 1 (1-2), 41-56.

Alagoa, Y, Elo O, Andrew, U and Ojukuli A, (2011) A Report on Aquaculture Value Chain Analysis in the Niger Delta. Foundation for Partnership Initiatives in the Niger Delta (PIND) $1^{\text {st }}$ Floor St. James Building, 167 Ademola Adetokunbo Crescent, Wuse II, Abuja, Nigeria.

Alarima, C. I. Kolawole, A., Fabusoro, E., Ajulo, A. A., Masunaga, T. and Wakatsuki, T. (2011). Knowledge and Training Needs of Farmers Adopting Sawah Rice Production Technology in Nigeria. Journal of Food, Agriculture \& Environment 9 (3\&4), 183-188.

Bene, C., Barange, M., Subasinghe, R., Pinstrup-Andersen, P., Merino, G., Hemre, G.I. \& Williams, M. (2015). Feeding 9 billion by 2050-putting fish back on the menu. Food Security, 7 (2), 261-274.

Dambatta, M.A., \& Sogbesan, O. A (2015). Socio-Economic and Profitability of Fisheries Enterprises in Kano State, Nigeria. International Journal of Novel Research in Humanity and Social Sciences, 2 (1), 72-83, Retrieved from www.noveltyjournals.com

Etwire, P.M., Dogbe, W., Wiredu, A.N., Martey, E., Etwire, E., Owusu R.K, \& Wahaga, E. (2013). Factors Influencing Farmer's Participation in Agricultural Projects: The case of the Agricultural Value Chain Mentorship Project in the Northern Region of Ghana. Journal of Economics and Sustainable Development, 4 (10), 36-43

FAO (2008) Fisheries management. 3. Managing fishing capacity. FAO Technical Guidelines for Responsible Fisheries. No. 4, Suppl. 3. 104p. Rome, Italy.

FAO (2012) The Prevention of losses in cured fish. FAO Fish Tech. Paper., (219): 87 p. ILOI Government of Norway (1984) Zmprousd Village Technology for Women's ActivitiesQ Manual for West Africa.

FAO (2016). Fisheries in the Drylands of Sub-Sahara Africa- "Fish comes with the rains". Building the Resilience for fisheries-dependent livelihoods to enhance food security and nutrition in the drylands, by Jeppe Kolding, Paul van Zwieten, Felix Marttin and Florence Poulain. FAO Fisheries and Aquaculture Circular No. 1118, Italy.

FAO (2018). The State of World Fisheries and Aquaculture 2018 - Meeting the Sustainable Development Goals. Rome, Italy. 
Gibson, D., and Sumaila U.R. (2017). "Determining the Degree of 'Small-scaleness' using Fisheries in British Columbia as an Example." Marine Policy (in press).

Ifabiyi, J.O., Banjoko I.K. and Komolafe S.E. (2017). Assessment of the Training Needs of Artisanal Fishers' in Asa Local Government Area of Kwara State, Nigeria. Nigerian Journal of Rural Extension and Development Vol. 11.

Ifabiyi J.O., (2019). Capacity Building Needs of Fisherfolks in Kogi and Kwara State, Nigeria. Unpublished Ph.D Thesis, University of Ilorin, Ilorin, Nigeria.

Kapadia F. (2002). International Centre for Living Aquatic Resources Management, NAGA, the ICLARM. Quarterly, 22 (2), 29-31.

Kyangwa .I. and K. Odonngkara, (2005): Sanitation, fish handling and artisanal fish processing within communities: socio-cultural influences. LVEMP Socio-economic research report 6. NARO-FIRRI,Jinga.

Martin, K.G. (2012). Assessing the Fit of Regression Models. Correll Statistical Consulting United State News No 68.

Okonta, A.A. \& Ekelemu J K., (2005). A preliminary study of Micro- Organisms associated with fish spoilage in Asaba, Southern Nigeria. Proceedings of the 20th Annual conference of Fisheries Society of Nigeria (FISON), Port- Harcourt 14th-18th November.

Okwu O.J, Yahaya M.A. and. Obinne C.P.O (2011) Analysis of Artisanal Fisher Folk Information Needs and Accessibility in Benue State, Nigeria. Asian Journal of Agricultural Sciences 3(5): 408-413, ISSN: 2041-3890.

Olaoye, O. J., \& Oloruntoba, A. (2011). Determinants of aquaculture technologies adoption among fish farmers in Obafemi-Owode Local Government Area of Ogun State, Nigeria. Journal of Humanities, Social Sciences and Creative Arts 5 (1), 37-48.

Olowoniyan F.O, Bolorunduro P.I, Dikko H. and Chindo H (2013). Preparation, Processing and Utilization of Fish Products. Extension Bulletin No 99, Home Economics Series no 8. NAERLS, Ahmadu Bello University Zaria.

Onuoha, G.C. (2009). Fundamental principles of fisheries science. New Edition Digital Press, Umuahia. 164p.

Onyebinama, U. A. U., \& Onyebinama I. C. (2010). Extension education on Entrepreneurship development in Nigeria agriculture. Agricultural journal, 5(2), 63- 69.

Owona, N. P. A, Nyaka, N. A., Ehabe, E. E., Chambon-Poveda, B. \& Bruneau, J. C. (2010). Assessment of training needs of rubber farmers in the south-west region of Cameroon. African Journal of Agricultural Research 5(17), 23-31

Samson, A., (2006). Production and Market Information Strategy for Fisheries Production: A Case Study of Fisher Folk Cooperatives in Ondo State Coastal Communities. University of Agriculture, Abeokuta.

Sumaila, U. R. (2017). Small-Scale Fisheries and Subsidies Disciplines: Definitions, Catches, Revenues, and Subsidies. Information Note. Geneva: International Centre for Trade and Sustainable Development (ICTSD). 